TAO, Vol. 17, No. 2, 405-427, June 2006

\title{
Cold-seep Carbonate Hardgrounds as the Initial Substrata of Coral Reef Development in a Siliciclastic Paleoenvironment of Southwestern Taiwan
}

\author{
Shih-Wei Wang ${ }^{1,2}$ Shou-Yeh Gong ${ }^{2}$, Horng-Sheng Mii ${ }^{3}$ and Chang-Feng Dai ${ }^{1, *}$
}

(Manuscript received 2 January 2006, in final form 24 May 2006)

\begin{abstract}
Abrupt facies changes from the underlying terrigenous mudstone of deep-water facies upward into reefal limestones were observed on Pleistocene scleractinian reefs in southwestern Taiwan. To reveal the initial mechanisms of reef development, we examined the lithologies and vertical facies changes of 7 outcrops and 37 borehole cores from the Takangshan Reef and performed petrographic and isotopic studies. Various occurrences of dolomitic mudstone were observed from 6 outcrops and in 11 borehole cores, containing massive dolomitic mudstones, carbonate pipes, dolomitic cobbles, and dolomitic pebbles. The $\delta^{13} \mathrm{C}$ values of 27 samples ranged from $-53.7 \%$ to $-10.4 \%$, indicating that the carbonate cements of these mudstones were all cold-seep carbonates in origin. The majority of the coldseep carbonates and a funnel-shaped structure packed with dolomitic cobbles were precipitated and formed within fine-grained siliciclastic mudstones. The wide occurrence of seep carbonates in the study area suggests hydrocarbon seepage having occurred extensively. The compact nature and associated large lucinid bivalves in massive cold-seep carbonates further indicate a pronounced, long-lasting seepage of methane occurring antecedently to the development of Takangshan Reef. A schematic model was proposed to illustrate the occurrence of various associations of lithologies and lithofacies. The erosional surfaces on siliciclastic mudstones and the funnel-shaped structure, as well as the exhuming of massive cold-seep carbonates may have occurred concurrently during a tectonically unstable time in SW Taiwan. The deposition of fossiliferous mudstone interfingered

\footnotetext{
${ }^{1}$ Institute of Oceanography, National Taiwan University, Taipei, Taiwan, ROC

2 Division of Geology, National Museum of Natural Science, Taichung, Taiwan, ROC

${ }^{3}$ Department of Earth Sciences, National Taiwan Normal University, Taipei, Taiwan, ROC

* Corresponding author address: Prof. Chang-Feng Dai, Institute of Oceanography, National Taiwan University, Taipei, Taiwan, ROC; E-mail: corallab@ntu.edu.tw
} 
with the conglomerate lithofacies represents a rapid facies transition from a siliciclastic (non-carbonate) to a carbonate environment. The root of this rapid facies change is presumed to be tectonic movement, probably related to the westward thrust migration in the Pleistocene foreland basin. The exposed massive seep carbonates provided a substrate for the encrustations of corals as well as coralline algae and might have played a crucial role in the initial development of coral reefs in a siliciclastic paleoenvironment. To our best knowledge, this is the first case in the world of cold-seep carbonates acting as an initial colonization hardground for hermatypic corals and corallines.

(Key words: Cold-seep carbonates, Coral reef, Hardground, Foreland basin, Lucinids)

\section{INTRODUCTION}

Modern coral reefs generally develop in clear, warm, well-lit tropical shallow marine environments. Excessive terrigenous sediments and accompanying nutrients are usually considered a threat to coral reef health and growth (Rogers 1990). However, several studies have shown that modern coral reefs can sometimes survive or develop in turbid waters (Johnson and Risk 1987; Tudhope and Scoffin 1994; Perry 2005). Modern coral reefs have developed in muddy environments on the Queensland Shelf of northeastern Australia (Hopley et al. 1983; Johnson and Risk 1987), southeast of Phuket in Thailand (Tudhope and Scoffin 1994; Scoffin and Le Tissier 1998), and off the western coast of Hammond Island in the Torres Strait, Australia (Woodroffe et al. 2000). However, these reefs did not initially grow on muddy substrates, but on rocky bottoms, shoreline gravel and boulders, muddy coral rubble banks, and coarsegrained sediments. The fossil record also implies that the development of coral reefs are compatible with terrigenous deposits (e.g., Weiss et al. 1978; Sanders and Baron-Szabo 2005). It seems that coral reefs develop in a variety of shallow marine environments if hardground or coarse-grained siliciclastic substrate is available.

A special mode of modern ahermatypic coral buildup development in deep-water, noncarbonate environments closely associated with hydrocarbon seeps has previously been proposed (Hovland 1990; Hovland et al. 1998). Hovland (1990) suggests that such buildups formed at locations containing high concentrations of bacteria and other microorganisms suspended in water columns resulting from seeping fluids, which would have provided energy and carbon sources. Precipitation of early diagenetic minerals may have occurred with sediment grains and skeletal remains being cemented together to produce a firm substratum. Eventually, such carbonate buildups would have developed extensively, depending on other environmental factors and the intensity of the fluid seepage. This model may explain paradoxical buildups, both modern and fossil ones, found in various sedimentary environments (Hovland 1990). However, this seepage hypothesis is still being debated (De Mol et al. 2002; Hovland and Risk 2003; Hovland 2005).

In this study, we examine the initial mechanisms of reef development at the Gutingkeng 
Formation of southwestern Taiwan. These Pleistocene coral reefs occur as lenticular bodies in a siliciclastic mudstone unit and were constructed mainly by shallow-water colonial corals, including Acropora, Acanthastrea, Cyphastrea, Favia, Favites, Goniopora, Goniastrea, Galaxea, Pachyseris, Porites, and Turbinaria, with locally abundant free-living corals such as Cycloseris, Fungia, Heliofungia, and Herpolitha (Yabe and Sugiyama 1935a, b; Hoeksema and Dai 1991). These scleractinian reefs developed on several local topographic highs that are closely associated with anticlines and faults in a Plio-Pleistocene foreland basin (Gong et al. 1996, 1998; Lacombe et al. 1997, 1999; Fig. 1). Several mud volcanoes in the vicinity are also closely related to the thrusts (Shih 1967; Fig. 1). Geochemical studies have revealed that the mud volcano fluids are composed of marine sedimentary pore water and the dehydrated water of clay minerals (Gieskes et al. 1992; You et al. 2004, Yeh et al. 2005). The exhaling gases of most mud volcanoes are methane-dominant (Yang et al. 2004). Active mud volcano fluid and

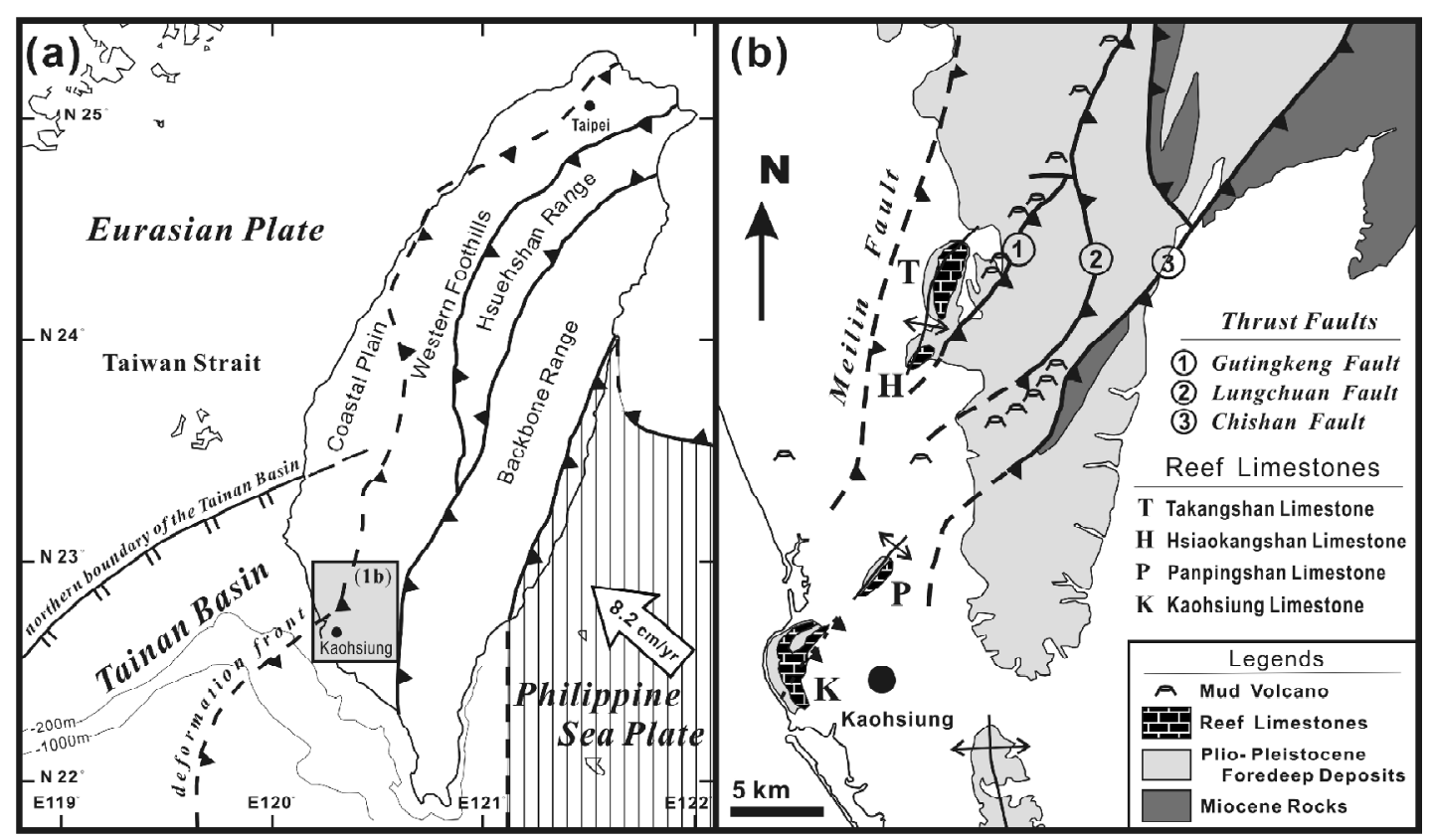

Fig. 1. (a) Tectonic setting and main structural units of Taiwan. Compiled from Teng (1992) and Lee (1992). Bold lines indicate major thrust faults; triangles are on the upthrown side. The large open arrow in the lower right corner shows the direction of convergence of the Philippine Sea Plate relative to the Eurasian Plate; moving rate is after Yu et al. (1997). (b) Map showing the locations of Pleistocene reef limestones and major structural features in southwestern Taiwan. Compiled from Shih (1967), Chinese Petroleum Corporation (1989, 1992), and Lacombe et al. (1999). 
gas expulsions probably occurred concurrently during the evolving of folds and thrusts in southwestern Taiwan.

It is believed that the thrust migration in the foreland basin caused rapid shallowing and formed local topographic highs along the anticlinal ridges that facilitated the development of coral reefs (Gong et al. 1998; Chow et al. 2001). Abrupt facies changes from the underlying terrigenous mudstone strata of deep-water facies upward into the reefal limestones were observed at the bottom of these reefs (Gong et al. 1996, 1998). However, it is still uncertain how these reefs initiated on the siliciclastic muddy substrates. Herein we demonstrate the possible mechanism that initiated the development of these coral reefs in a siliciclastic paleoenvironment from a detailed study on the lithologies and facies changes.

\section{MATERIALS AND METHODS}

The two quarries in Takangshan were chosen for field studies (Fig. 2). We focused on vertical facies changes from the underlying siliciclastic mudstones upward into the basal parts of the Takangshan Reef limestone. The field study sites were designated as Outcrops 1 to 7 (Fig. 2). Thirty-seven borehole cores stored in the National Museum of Natural Science (NMNS) which show facies change strata were also examined. These include 19 boreholes from the quarry at northwestern (NW) Takangshan and 18 boreholes from eastern (E) Takangshan(Fig. 2).

Rock specimens were examined using hand samples, polished slabs, and thin sections, under a light microscope. In addition, typical samples of siliciclastic mudstone and fossiliferous mudstone were picked from the longest $(68 \mathrm{~m}$ ) borehole core (Core 9 of $\mathrm{E}$ Takangshan) for grain size analysis. Owing to weak consolidation, samples were loosened in distilled water within 1 to 2 weeks, and only gentle shaking was required before sieving operations. Grains of each grade were identified using a binocular microscope, and mineralogies were determined by X-ray diffraction (XRD) analysis. In addition, the very fine to coarse sand (grain size $=0.062-1.0 \mathrm{~mm}$ ) of the fossiliferous mudstone was well mixed. About half of the sample (dry wt $=5.59 \mathrm{~g}$ ) was soaked with a $10 \% \mathrm{HCl}$ solution to remove skeletal carbonates, then reweighed to obtain the relative percentage of carbonate and terrigenous components.

Carbonate-cemented mudstones for mineralogical composition analyses were sampled ( $n=105)$ using a hand-held microdrill or steel vise, and veined samples were avoided. Then 27 samples with single mineralogical composition were selected for carbon and oxygen isotopic analyses. Bulk mineralogy was determined by XRD on powdered samples using a Rigaku diffractometer with $\mathrm{Cu} \mathrm{K} \alpha$ radiation $\left(1^{\circ} \mathrm{min}^{-1}\right)$ at the NMNS. Carbon and oxygen isotope compositions of samples were analyzed using a Micromass IsoPrime mass spectrometer equipped with a Multicarb automatic system at the National Taiwan Normal University. Rock powders were reacted with $100 \%$ phosphoric acid at $90^{\circ} \mathrm{C}$. The carbonate standard NBS-19 (National Bureau of Standards; $\delta^{13} \mathrm{C}=1.95 \%, \delta{ }^{18} \mathrm{O}=-2.20 \%$ ) was used to calibrate to the Vienna Peedee belemnite (V-PDB) standard. The average precision based on the NBS-19 carbonate standard was $0.03 \%$ for $\delta^{13} \mathrm{C}$ and $0.06 \%$ for $\delta^{18} \mathrm{O}(n=177)$. No correction was made for the difference in the phosphoric acid fractionation factors between dolomite and calcite. 


\section{LITHOLOGIES}

Five lithologies were recognized; they were siliciclastic mudstone, fossiliferous mudstone, bioclastic floatstone, dolomitic mudstone, and conglomerate.

\subsection{Siliciclastic Mudstone}

The typical siliciclastic mudstone was composed of fine-grained siliciclastics (wt\% of clay and silt fractions approximately $=98 \%$ ) (Fig. 3a, Table 1). Most of the siliciclastic mud-

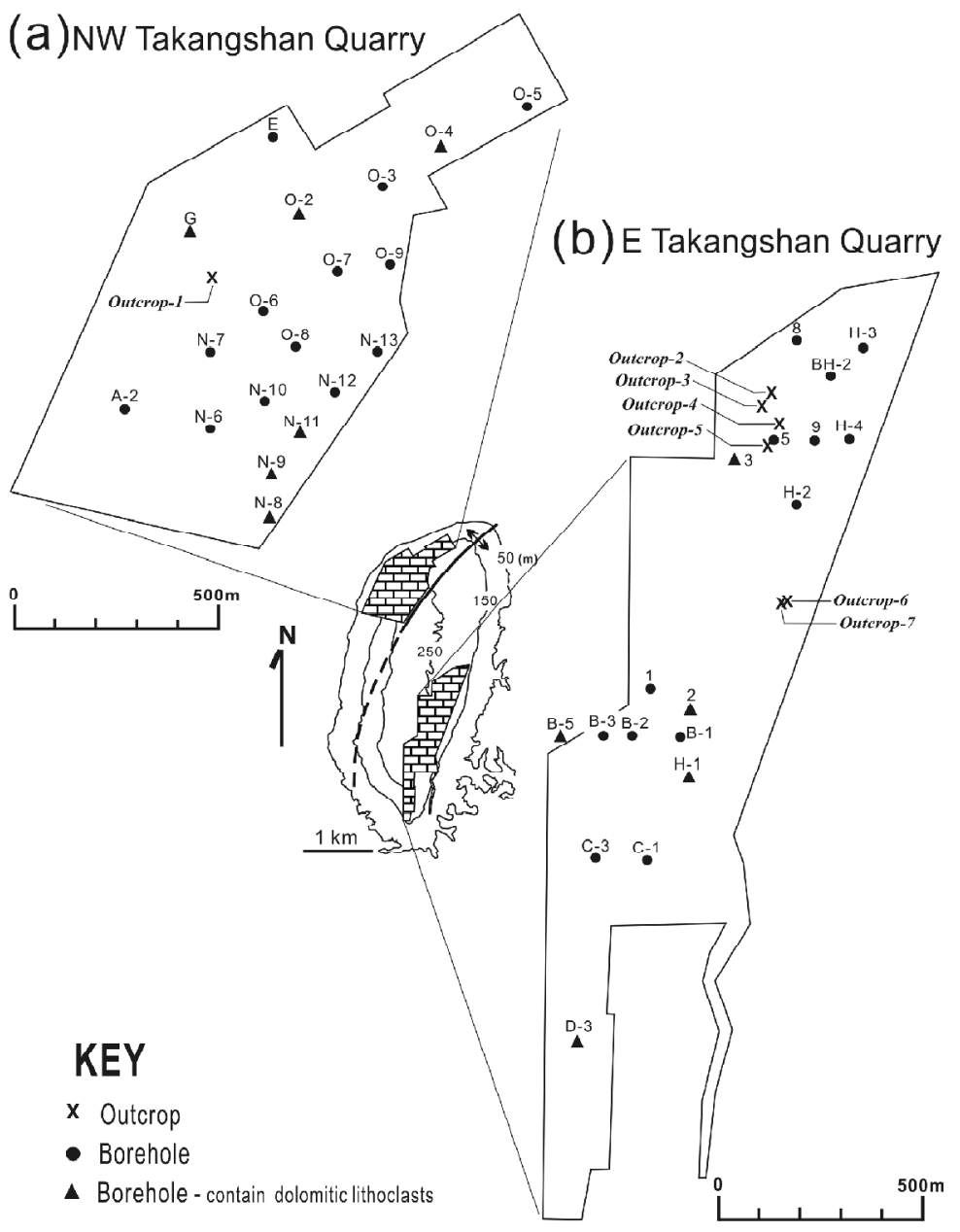

Fig. 2. Index maps showing sites of borehole cores and outcrops in the NW Takangshan (a) and E Takangshan (b) quarries. Scales for both index maps are shown on the bottom. Location of the Takangshan was shown in Fig. 1b. 
stones are monotonous and with no discernible bedding features (Figs. 4a, b), but some subangular to subrounded dolomitic mudstone cobbles and pebbles were observed at 4 outcrops and in 10 borehole cores (Figs. 4c, d).

\subsection{Fossiliferous Mudstone}

Fossiliferous mudstone is siliciclastic mudstone containing abundant bioclasts (Fig. 5b, Table 2), and this varied in thickness from $15 \mathrm{~cm}$ to more than $2 \mathrm{~m}$. This weakly consolidated lithology was observed at Outcrops 1, 4, and 7 (Figs. 5a, b) and in all borehole cores except one (Core N-10) at NW Takangshan. Faint bedding and mud chips (Fig. 5c) could be observed locally at the outcrops. Some subangular to subrounded dolomitic mudstone cobbles and pebbles occurred in Core 3 and $\mathrm{H}-1$ at the E Takangshan quarry. The majority of coarse bioclasts within this lithology were abraded and/or stained a brown color, and only a few intact colonial coral, free-living fungiids, and clypeiform urchins were found, suggesting that most of the bioclasts were not deposited in situ. The results of acid digestion showed that only $12.5 \%$ was acid insoluble residues, revealing that the majority of the sand grade fraction of this lithology consisted of bioclasts rather than terrigenous siliciclastics.

a. Siliciclastic mudstone

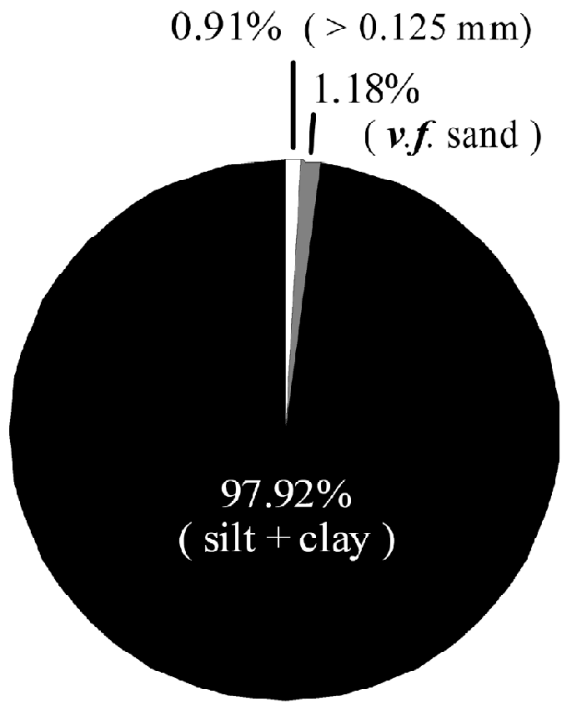

\section{b. Fossiliferous mudstone}

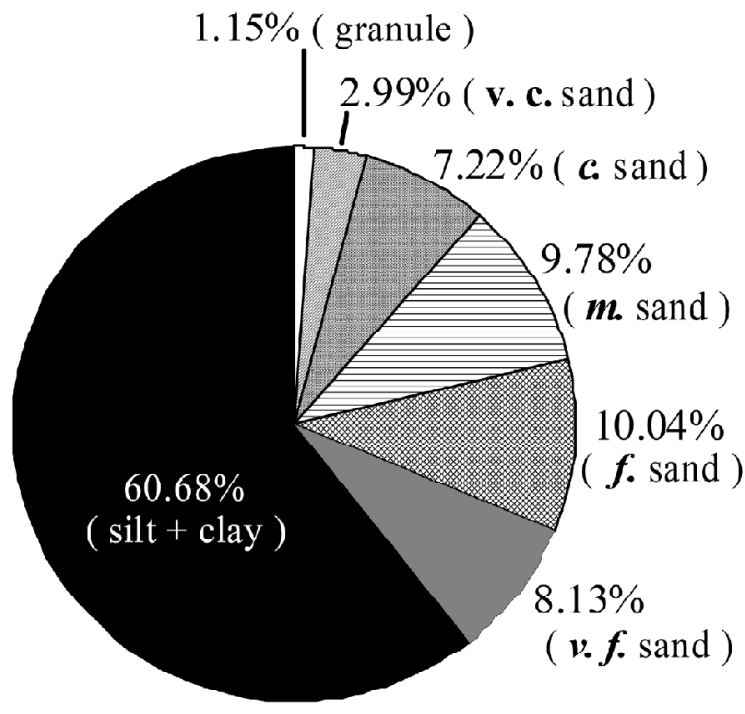

$(\boldsymbol{v} .=$ very $; \boldsymbol{c} .=$ coarse $; \boldsymbol{m} .=$ medium; $\boldsymbol{f} .=$ fine $)$

Fig. 3. Pie charts showing the results of sieve analyses for the siliciclastic mudstone and fossiliferous mudstone. See Tables 1 and 2 for details of the sieve grade fractions and compositions. 
Wang et al.

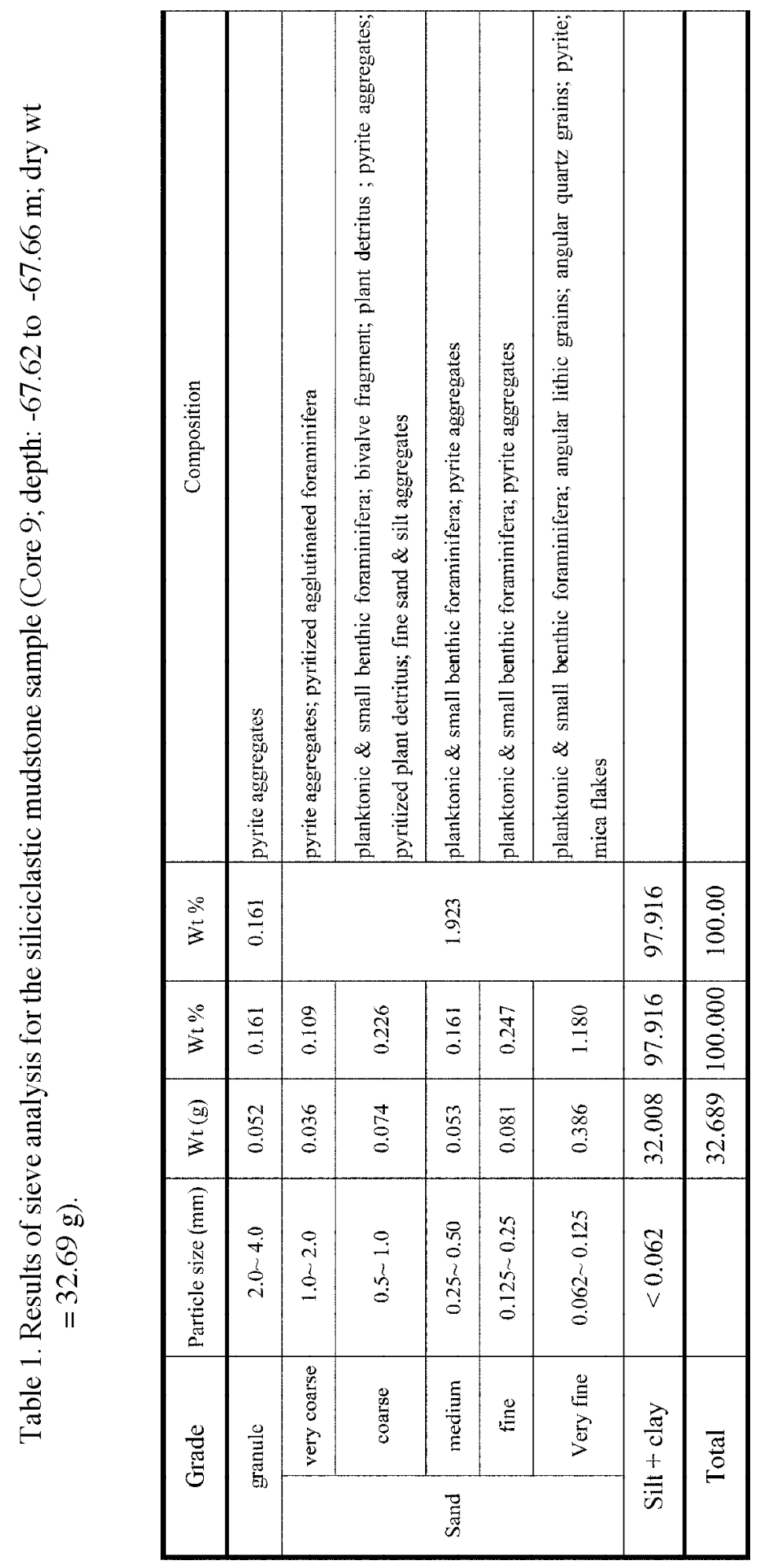




\subsection{Bioclastic Floatstone}

This cemented bioclastic limestone consists of rhodoliths, large foraminifera, smaller benthic foraminifera, colonial coral fragments, free-living fungiids, bivalves, gastropods, bryozoans, sea urchin spines, and geniculated coralline algae in a micritic matrix. This lithology constituted the basal part of the Takangshan Reef limestone in the study area(Figs. 4b, 5a, b).
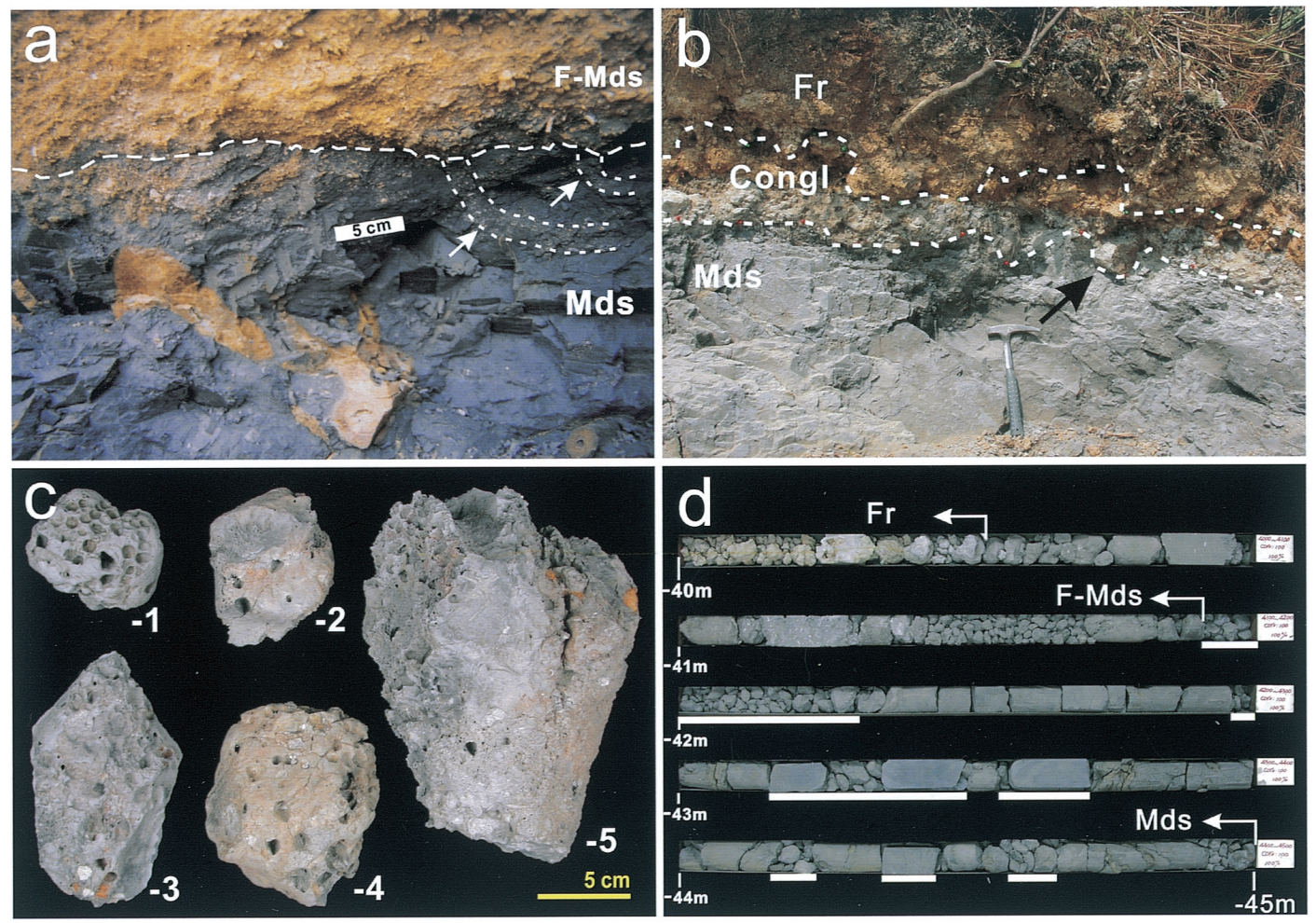

Fig. 4. (a) Close-up of Outcrop 1 showing abrupt facies changes from the underlying siliciclastic mudstone (Mds) upward into the overlying fossiliferous mudstone (F-Mds). White arrows indicate tubular burrows that were truncated at the facies contact. (b) Vertical facies change at Outcrop 2. The arrow indicates a dolomitic carbonate pipe. Hammer length $=33 \mathrm{~cm}$. (Congl: conglomerate; Fr: bioclastic floatstone) (c) Photos of dolomitic cobbles (nos. 1 to 4) and a broken carbonate pipe (no. 5) from Outcrop 4 showing dense bivalve borings. The $\delta^{13} \mathrm{C}$ values of cobbles nos. 1 to 3 are $-48.4 \%$, $-48.1 \%$, and $-50.6 \%$ V-PDB, respectively. (d) Photo of Core 2 (depth $40 \sim 45 \mathrm{~m}$ ) from the E Takangshan quarry. Sections of Mds that contain dolomitic cobbles and pebbles are underlined with bold lines. 


\subsection{Dolomitic Mudstone}

This lithology is represented by the fine-grained mudstones that were cemented mainly by microcrystalline dolomites. They occurred as well-lithified massive rocks, cobbles, pebbles, and carbonate pipes in the siliciclastic mudstone, and/or as redeposited cobbles, pebbles, and carbonate pipes in the conglomerate and fossiliferous mudstones. Majorities of the dolomitic mudstones were precipitated and/or formed within the fine-grained siliciclastic mudstones. The results of XRD analyses ( $n=115$ ) showed that these mudstones were cemented mainly by dolomite. Therefore, this lithology was named the 'dolomitic mudstone'.

Massive dolomitic mudstones were observed at Outcrops 3, 5, and 6. The lateral extent of this lithology could reach $13 \mathrm{~m}$, and the thickness varied from 0.5 to more than $3.2 \mathrm{~m}$. Many
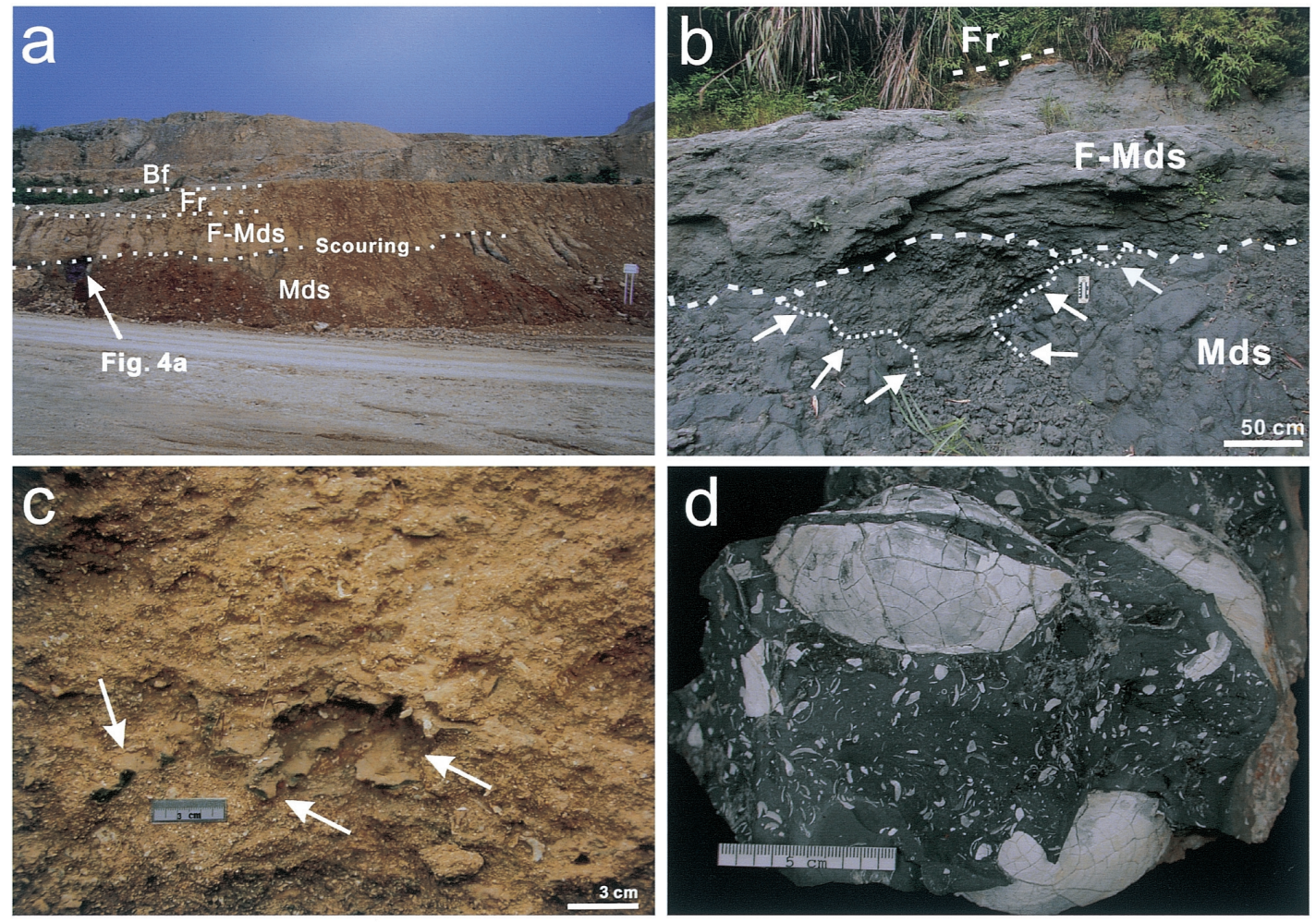

Fig. 5. (a) Vertical facies change at Outcrop 1. (Mds: siliciclastic mudstone; F-Mds: fossiliferous mudstone; Fr: bioclastic floatstone; Bf: foliaceous coral boundstone) (b) White arrows indicate a funnel-shaped structure at outcrop 7. (c) Close-up of F-Mds at Outcrop 1. White arrows indicate unconsolidated mud chips. (d) Three large fossil lucinids in massive dolomitic mudstone collected from Outcrop 5. 


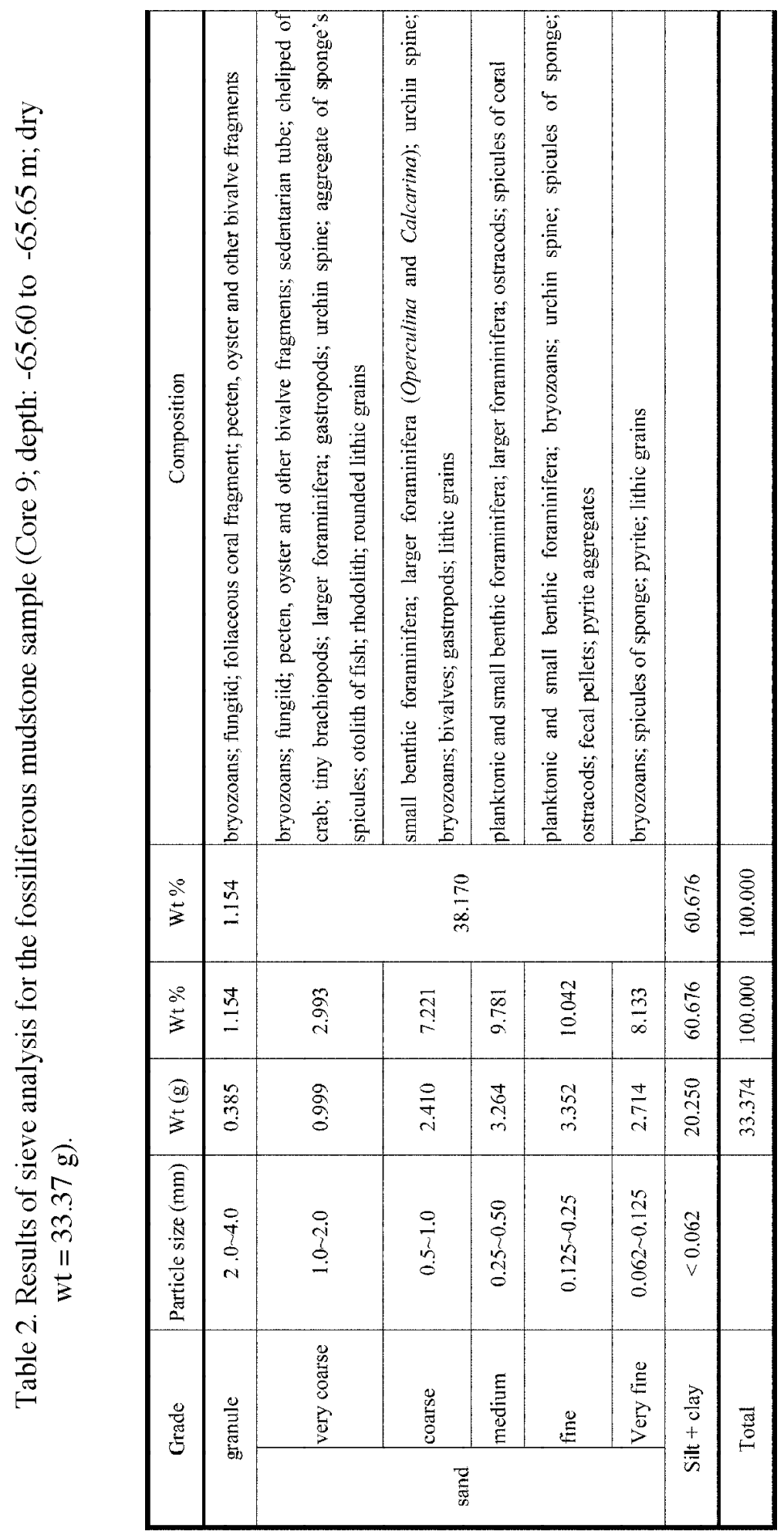


fossil lucinids preserved in a living position were frequently found in this outcropped lithology. For example, at Outcrop 5, more than 100 large fossil lucinids (Fig. 5d), several turrid, trochid, and turbinid gastropods, and a few mytilid bivalves were found in the blocks excavated from the outcrop.

Dolomitic cobbles and pebbles composed of fine-grained dolomitic mudstone could be observed from (i) mudstones exposed at Outcrops 2, 4, 6, and 7; (ii) the conglomerate exposed at Outcrop 2 (Fig. 6a); (iii) mudstones in 6 borehole cores (Cores G, N-8, N-9, N-11, O-2, and O-4) at the NW Takangshan quarry and 4 cores (Cores 2, 3, B-5, and D-3) at the E Takangshan quarry (Fig. 4d); and (iv) the fossiliferous mudstone in 2 borehole cores (Cores 3 and H-1) at the E Takangshan quarry. Most of the dolomitic cobbles and pebbles in the borehole cores were recognized from the siliciclastic mudstone; they were neither encrusted nor bored into by organisms except those from Outcrop 4 which had been densely bored into by bivalves (Fig. 4c). At Outcrop 7, a funneled structure was observed in the non-consolidated siliciclastic mudstone (Fig. 5b), and this structure was filled with dolomitic cobbles and pebbles.

Carbonate pipes were observed in the mudstones exposed at Outcrops 4 and 7 (Fig. 6b). Redeposited carbonate pipes were observed in the conglomerate exposed at Outcrop 2(Fig. 4b), and in the fossiliferous mudstone of Core 3 from the $\mathrm{E}$ Takangshan quarry. These carbonate pipes ranged from 3 to $30 \mathrm{~cm}$ in diameter, with an elliptical or nearly circular cross-section. Each carbonate pipe possesses a hollow or filled conduit-like tubular structure at its center. Orientations of most of these carbonate pipes were vertical, while some were slightly tilted or nearly horizontal. No encrusting organisms were found on the outer walls of the carbonate pipes except for some scars produced by boring.

\subsection{Conglomerate}

The conglomerate consisted of angular to well-rounded carbonate-cemented cobbles and pebbles in a matrix of weakly consolidated mud. The lateral extent of this lithology could be traced to $5 \mathrm{~m}$, and the thickness varied from 10 to more than $30 \mathrm{~cm}$ (Fig. 4b). Weakly consolidated cobbles with fractures and/or brecciated fabrics (Fig. 6a), carbonate pipes (Fig. 4b), redeposited large lucinids, and free-living fungiids were also observed.

\section{VERTICAL FACIES CHANGE}

Four types of vertical facies change from the underlying mudstone upward into the Takangshan Reef were discriminated based on close examination of the 7 outcrops and 37 borehole cores.

\subsection{Siliciclastic Mudstone- Fossiliferous Mudstone- Bioclastic Floatstone}

This type of facies change was observed at 3 outcrops (Outcrops 1, 4, and 7) and in 36 borehole cores (Figs. 4d, 5a, b). At Outcrop 1, the tubular burrows of the siliciclastic mudstone lacked outer linings and were infilled by bioclasts and muds (Fig. 4a), suggesting a firmground nature for the mudstones, i.e., a stiff but uncemented substrate. Both the top and bottom of the 

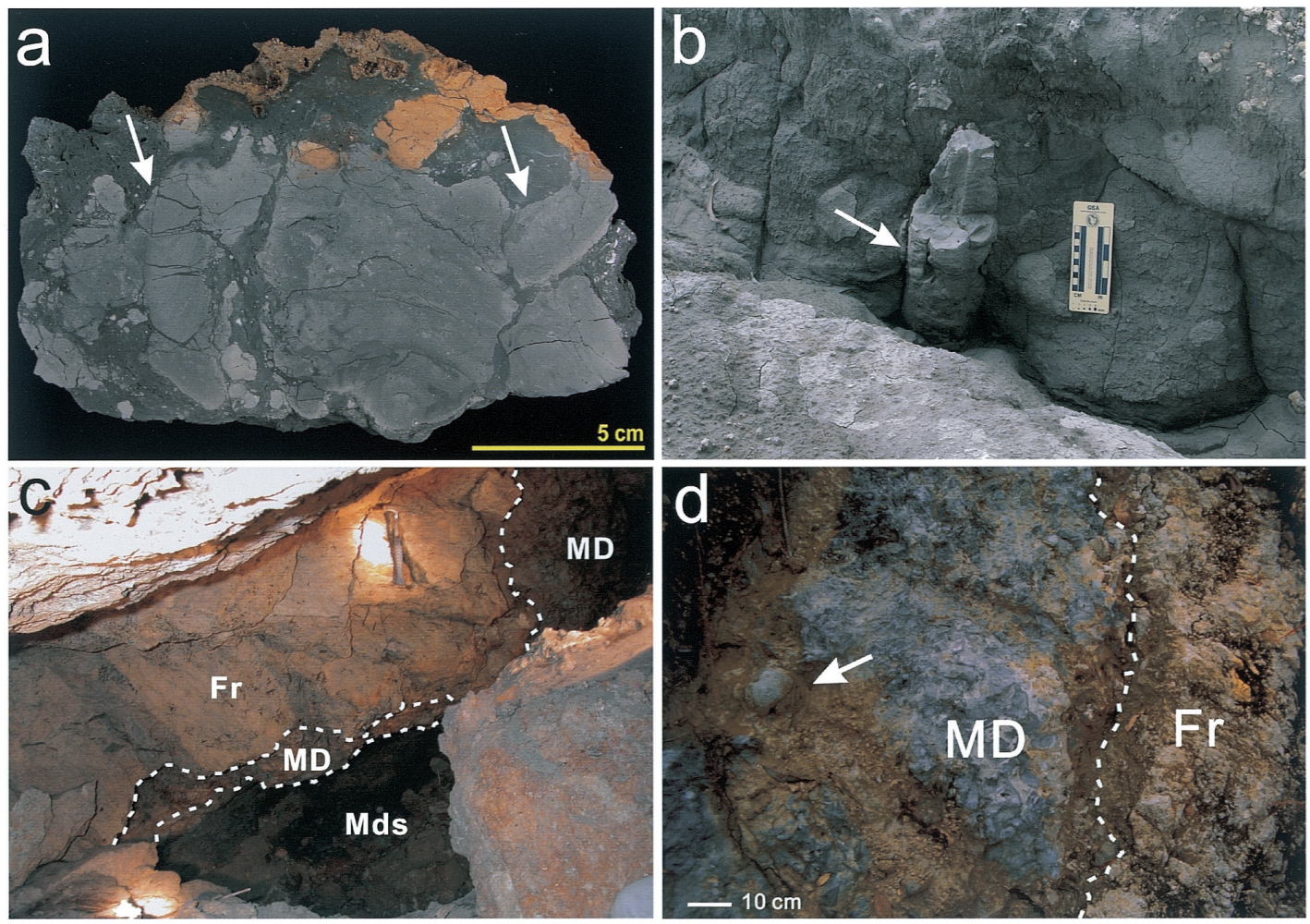

Fig. 6. (a) Polished slab of conglomerate from Outcrop 2 showing fractured and brecciated dolomitic cobbles (arrowed) in a matrix of weakly consolidated mud. (b) The arrow indicates a dolomitic carbonate pipe observed at Outcrop 4. (c) A view of Outcrop 6 exposed within a cave, showing the transition bottom and the irregular scouring top contacts of massive dolomitic mudstones (MD). (d) The partly exposed massive dolomitic mudstone at Outcrop 3 was directly overlaid by bioclastic floatstone (Fr) with an irregular contact. The arrow indicates an in situ fossil lucinid, Loripes goliath.

fossiliferous mudstone with a vertical thickness of about $60 \mathrm{~cm}$ were bounded by scoured contacts. Many vertically oriented carbonate pipes were observed in the siliciclastic mudstone exposed at Outcrops 4 (Fig. 6b) and 7 (Fig. 5b). Broken carbonate pipes and dolomitic cobbles with dense bivalve bores (Fig. 4c) were observed at Outcrop 4. At Outcrop 7, a funnel-shaped structure was developed within the mudstone and was truncated at the upper facies contact, forming a convex upper boundary (Fig. 5b). This is analogous to a mud volcano conduit, in which the semi-consolidated cobble- and pebble-sized mudstones are expelled onto the surrounding muddy substrata and eventually embedded in the unconsolidated matrix of siliciclastic mudstones. Fossils of the fossiliferous mudstone that exposed at this outcrop consisting of 
fragments of foliaceous corals, rhodoliths, pectens, oysters, turbinid gastropods, free-living corals Cycloseris, and an intact coral colony of Stylocoeniella guentheri. A few carbonatecemented cobbles were observed at the bottom of this lithology. These carbonate-cemented cobbles, pebbles, and carbonate pipes were also observed in siliciclastic mudstones and/or fossiliferous mudstones in 11 borehole cores (e.g., Fig. 4d).

\subsection{Siliciclastic Mudstone- Bioclastic Floatstone}

This type of facies change occurred only in Core N-10 of NW Takangshan. In this core, the vertical facies change occurred abruptly from the siliciclastic mudstone upward into the basal part of Takangshan Reef limestone, showing strong contrast to those that occurred in the 36 other borehole cores. The fossil burrows in the mudstone were truncated on the facies contact and infilled by granule- to pebble-sized limestones.

\subsection{Siliciclastic Mudstone- Conglomerate- Bioclastic Floatstone}

This type of facies change was observed only at Outcrop 2 (Fig. 4b). The vertical facies changes from the underlying siliciclastic mudstone upward into conglomerate, and then into Takangshan Reef limestone which occurred abruptly within $30 \mathrm{~cm}$. An encrusting coral preserved in situ was found $40 \mathrm{~cm}$ above the bottom of the bioclastic floatstone, suggesting a rapid facies change from bioclastic floatstone to coral boundstone. Both the top and bottom of the muddy conglomerate were bounded by scoured contacts. Many well-cemented dolomitic cobbles with negative $\delta^{13} \mathrm{C}$ values were collected from the siliciclastic mudstone (Table 3).

\subsection{Siliciclastic Mudstone- Massive Dolomitic Mudstone- Bioclastic Floatstone}

This type of facies change occurred at Outcrops 3, 5, and 6, although not all of the massive dolomitic mudstones were well exposed. This type of facies change is best represented by Outcrop 6 that mainly exposed in a cave. Some carbonate-cemented cobbles were observed from the underlying siliciclastic mudstone. The facies change from the underlying siliciclastic mudstone upward into massive dolomitic mudstone was transitional. However, the vertical facies change from the underlying massive dolomitic mudstones to bioclastic floatstone was abrupt, suggesting the results of bottom scouring (Fig. 6c). Localized coralline algae and scleractinian corals encrusted on the top of massive dolomitic mudstones was observed at Outcrop 6 with a lateral extent of $24 \mathrm{~cm}$ and a maximum thickness of $11 \mathrm{~cm}$. Abrupt facies changes were also observed at Outcrop 3 where the partly exposed massive dolomitic mudstone was directly overlain by the bioclastic limestone with an irregular contact (Fig. 6d). At Outcrop 5, the massive dolomitic mudstone was encrusted by scleractinian corals and coralline algae, then overlain by the bioclastic floatstone (Figs. 4a, 5a, c). Vertical thickness of this encrustation varied from 16 to $20 \mathrm{~cm}$ and was constructed firstly by encrusting Porites and Favia, then by encrusting coralline algae and faviids, and finally by Porites. Many bivalves that bored into this encrustation were observed, including Parapholas quadrizonata, Jouannetia sp., and Lithophaga sp.. Thin sections of this encrustation (Fig. 8c) revealed sessile organisms other than corallines, such as encrusting bryozoans, foraminifera Acervulina, and barnacles. 
Larger foraminifera, oysters, pectens, crab carapaces, and coral fragments of Pachyseris speciosa, Porites, and Acropora were observed from the bioclastic floatstone.

\section{RESULTS OF STABLE ISOTOPE ANALYSES}

The carbon and oxygen stable isotope compositions of 27 samples of carbonate-cemented mudstone were analyzed. The $\delta^{13} \mathrm{C}$ values of 27 rock samples ranged from $-53.7 \%$ to $-10.4 \% 0$ (Fig. 7, Table 3). The massive dolomitic mudstone of Outcrop 5 showed the most-negative $\delta^{13} \mathrm{C}$ value. The dolomitic cobbles and pebbles yielded values that ranged from $-50.8 \%$ to

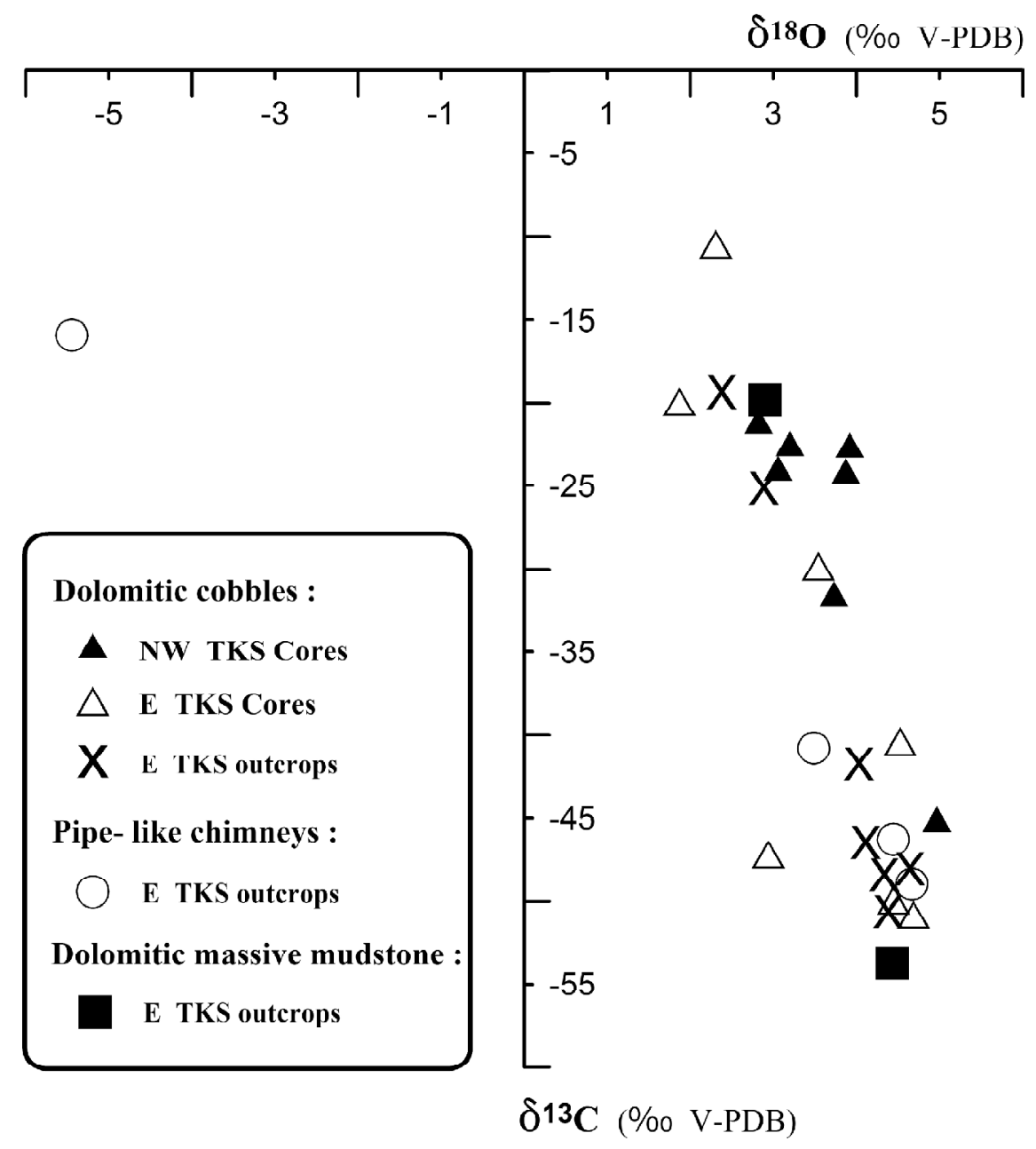

Fig. 7. Plots of $\delta^{13} \mathrm{C}$ and $\delta^{18} \mathrm{O}$ values for 27 carbonate-cemented mudstones. See Table 3 for the sample locations and occurrences. 
$-10.4 \%$. The $\delta^{13} \mathrm{C}$ values of the dolomitic carbonate pipes ranged from $-49.0 \%$ to $-40.8 \%$. One calcitic carbonate pipe yielded a $\delta^{13} \mathrm{C}$ value of $-15.9 \%$. The $\delta{ }^{18} \mathrm{O}$ values of 26 dolomitic samples were positive $(1.9 \%$ to $5.0 \%$ ), whereas a calcitic sample yielded a value of $-5.4 \%$ (Fig. 7; Table 3).

\section{DISCUSSIONS}

\subsection{The Dolomitic Mudstones Are Cold-Seep Carbonates}

The fossil macrofauna of the massive dolomitic mudstones was dominated by large lucinids, and most of the fossil lucinids on the outcrop were preserved in living positions. These are features typical of ancient seep assemblages (Bottjer et al. 1995). The co-occurrence of fossil

Table 3. Isotopic compositions of carbonate-cemented mudstones from the Takangshan (TKS).

\begin{tabular}{|c|c|c|c|c|}
\hline Quarry & Outcrop/Core: depth (m) & Occurrences & $\delta^{13} \mathrm{C} \%$ & $\delta^{18} \mathrm{O} \%$ \\
\hline NW TKS & Core G: $24.14 \sim 24.16$ & dolomitic cobble in mudstone & -24.2 & 3.1 \\
\hline NW TKS & Core N-8: 59.00 & dolomitic cobble in mudstone & -31.7 & 3.7 \\
\hline NW TKS & Core N-8: $61.68 \sim 61.69$ & dolomitic cobble in mudstone & -45.3 & 5.0 \\
\hline NW TKS & Core N-9: $60.54-60.55$ & dolomitic cobble in mudstone & -24.4 & 3.9 \\
\hline NW TKS & Core N-11: $53.82 \sim 53.83$ & dolomitic cobble in mudstone & -21.4 & 2.8 \\
\hline NW TKS & Core O-2: 18.07 & dolomitic cobble in mudstone & -22.7 & 3.2 \\
\hline NW TKS & Core 0-4: $28.00-28.02$ & dolomitic cobble in mudstone & -22.8 & 3.9 \\
\hline E TKS & Outcrop 2 & dolomitic cobble in mudstone & -19.4 & 2.4 \\
\hline E TKS & Outcrop 2 & dolomitic cobble in mudstone & -41.8 & 4.0 \\
\hline E TKS & Outcrop 2 & dolomitic cobble in mudstone & -46.5 & 4.1 \\
\hline E TKS & Outcrop 2 & dolomitic cobble in mudstone & -25.2 & 2.9 \\
\hline E TKS & Outcrop 3 & Massive dolomitic mudstone & -19.9 & 2.9 \\
\hline E TKS & Outcrop 3 & calcitic pipe, collected from massive dolomitic mudstone & -15.9 & -5.4 \\
\hline E TKS & Outcrop 4 & dolomitic pipe in mudstone & -46.3 & 4.4 \\
\hline E TKS & Outcrop 4 & dolomitic pipe in mudstone & -49.0 & 4.7 \\
\hline E TKS & Outcrop 4 & dolomitic pipe in mudstone & -40.8 & 3.5 \\
\hline E TKS & Outcrop 4 & $\begin{array}{l}\text { dolomitic cobble in mudstone (hardground for boring } \\
\text { bivalves) }\end{array}$ & -50.6 & 4.4 \\
\hline E TKS & Outcrop 4 & $\begin{array}{l}\text { dolomitic cobble in mudstone (hardground for boring } \\
\text { bivalves) }\end{array}$ & -48.1 & 4.6 \\
\hline E TKS & Outcrop 4 & $\begin{array}{l}\text { dolomitic cobble in mudstone (hardground for boring } \\
\text { bivalves) }\end{array}$ & -48.4 & 4.3 \\
\hline ETKS & Outcrop 5 & massive dolomitic mudstone & -53.7 & 4.4 \\
\hline E TKS & Core 2: $41.98 \sim 42.00$ & dolomitic cobble in mudstone & -50.8 & 4.7 \\
\hline ETKS & Core $2: 44.6$ & dolomitic cobble in mudstone & -49.9 & 4.4 \\
\hline E TKS & Core 3: $19.19 \sim 19.20$ & dolomitic cobble in fossiliferous mudstone & -19.9 & 1.9 \\
\hline E TKS & Core 3: $19.99 \sim 20.00$ & dolomitic cobble in mudstone & -40.4 & 4.5 \\
\hline E TKS & Core B-5: $33.45 \sim 33.47$ & dolomitic cobble in mudstone & -10.4 & 2.3 \\
\hline E TKS & Core D-3: $22.36 \sim 22.38$ & dolomitic pebble in mudstone & -47.2 & 2.9 \\
\hline E TKS & Core H-1:27 & dolomitic cobble in fossiliferous mudstone & -29.8 & 3.5 \\
\hline
\end{tabular}


lucinids and carbonate-cemented mudstones in the study area is likely analogous to the Jurassic 'pseudobioherm' in SE France (Gaillard et al. 1992), the Cretaceous 'seep-related limestone mounds' of NE Greenland (Kelly et al. 2000), the 'Tepee Buttes' in the Cretaceous Pierre Shale Formation of Colorado (USA) (Kauffman et al. 1996), the Miocene 'calcari a Lucina' (limestones with Lucina sp.) in the Italian north Apennines (Conti and Fontana 1999), and the Cenozoic seep-related Type III chemosynthetic assemblages in Japan (Majima et al. 2005).

The existing species of the Lucinidae are burrow-dwelling bivalves that occur globally over a wide range of marine habitats from intertidal to deep sea (Fisher 1990). Many lucinids burrow deeply and live near the interface of oxic and anoxic zones, or within the latter (Taylor and Glover 2000). All known species of the Lucinidae possess sulfide-oxidizing, chemosymbiotic bacteria housed in bacteriocytes of their gill filaments. Chemosymbiosis was suggested to be an inherent character of this family, which can be traced to the Silurian lucinid Ilionia (Liljedahl 1992; Taylor and Glover 2000).

The features of dolomitic mudstones of the study area, including clotted and stromatactoid petrographic fabrics (Fig. 8a), carbonate pipes (Fig. 6b), co-occurrence of fossil lucinids(Fig. 5d), and active tectonic settings (McDonnell et al. 2000), suggest that they are probably the coldseep carbonates. It has been shown that those carbonates formed at methane-seeps are typified by low $\delta^{13} \mathrm{C}$ values (reviewed in Peckmann and Thiel 2004). The $\delta^{13} \mathrm{C}$ values obtained from 27 rock samples of carbonate-cemented mudstones ranged from $-53.7 \%$ to $-10.4 \%$ (Table 3 ), which further verify this speculation.

Those massive cold-seep carbonates were characterized by abundant chemosynthetic lucinids suggesting that they were possibly formed beneath the oxic zone of sediments, perhaps no deeper than several centimeters to a few meters below the muddy seafloor (Ritger et al. 1987; Gaillard et al. 1992; Campbell and Bottjer 1993). However, a few epibenthic mollusks (turrid, trochid, and turbinid gastropods, and mytilid bivalves) associated with cold-seep carbonates were also observed at Outcrop 5, suggesting that parts of the cold-seep carbonates might have been exposed to the muddy seafloor.

\subsection{Carbon and Oxygen Stable Isotope Compositions of Cold-Seep Carbonates}

Biogenic methane is extremely depleted in ${ }^{13} \mathrm{C}$ and exhibits $\delta^{13} \mathrm{C}$ values in the range of $-50 \%$ to $-110 \%$ (Whiticar 1999), whereas thermogenic methane typically yields values ranging from $-30 \%$ to $-50 \%$ (Sackett 1978). In addition, the $\delta^{13} \mathrm{C}$ values of the cold-seep carbonates are generally higher than those of seeping hydrocarbons at the same sites. The very low $\delta^{13} \mathrm{C}$ values of ancient carbonates would indicate a biogenic methane source (Peckmann and Thiel 2004; Pierre and Rouchy 2004). Accordingly, the $\delta^{13} \mathrm{C}$ values of 27 rock samples of cold-seep carbonates are possibly the result of a mixture of deep thermogenic hydrocarbons and shallow biogenic methane (Díaz-del-Río et al. 2003).

The $\delta{ }^{18} \mathrm{O}$ values of 26 dolomitic samples are positive and range from $1.9 \%$ to $5.0 \% 0$. Although the high $\delta{ }^{18} \mathrm{O}$ values of seep carbonates have been ascribed to the dissociation of gas hydrates at modern seeps, this approach has not been successfully applied to fossil coldseep carbonates (reviewed in Peckmann and Thiel 2004). Alternatively, the higher $\delta^{18} \mathrm{O}$ val- 
ues of the 26 samples may represent the influences of cold formation water or the release of ${ }^{18} \mathrm{O}$-enriched water from dissociation of gas hydrates. It has been proposed that the $\delta{ }^{18} \mathrm{O}$ values of carbonates shift toward lower values during rock diagenetic alterations (Allen and Matthews 1982). The calcitic carbonate pipe that yielded negative $\delta{ }^{18} \mathrm{O}$ values $(-5.4 \%)$ was collected from the massive cold-seep carbonate that exhibited positive $\delta{ }^{18} \mathrm{O}$ values $(2.9 \%)$. This was probably the result of carbonate formed with different seeping fluid sources or partly altered during diagenesis.
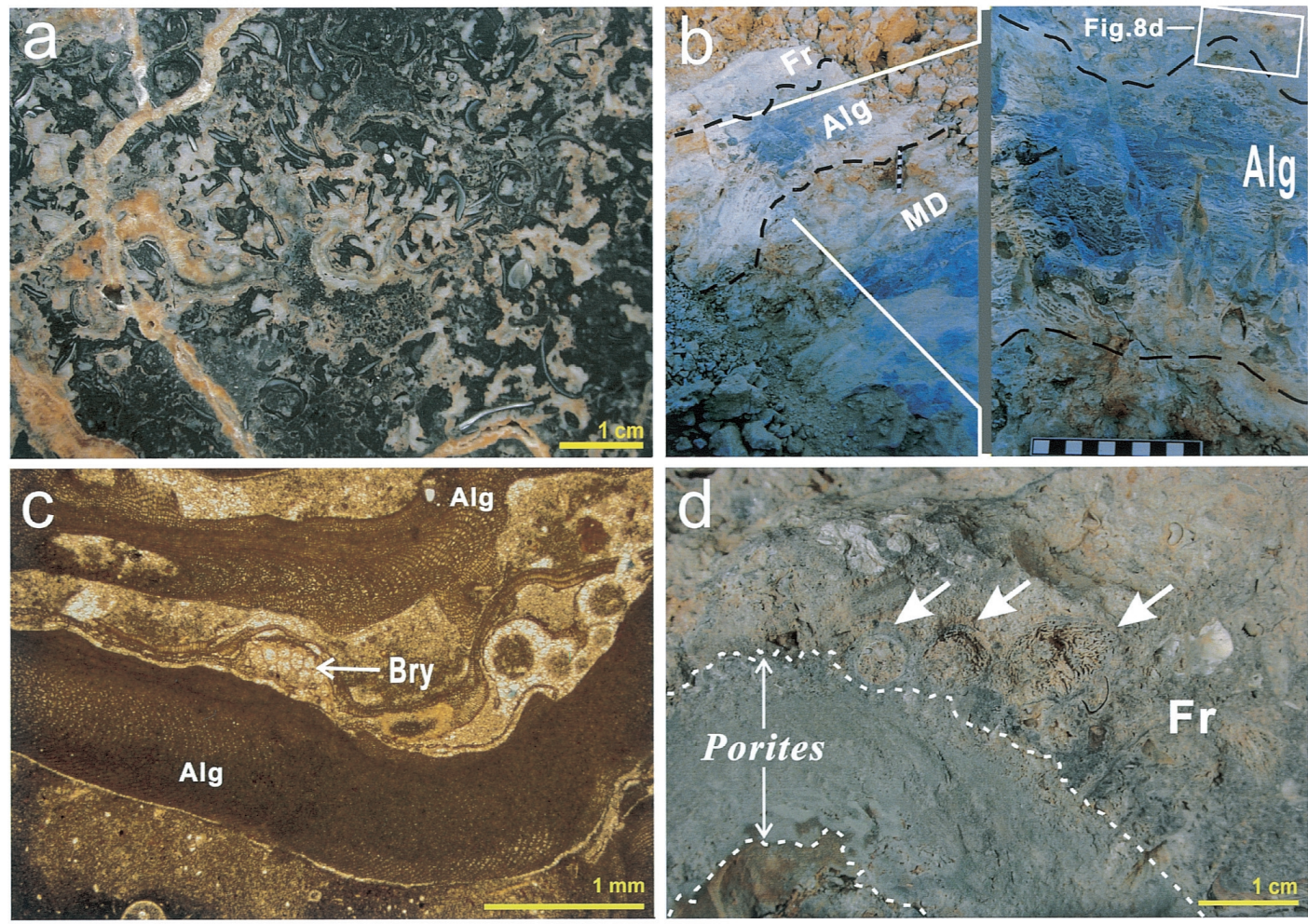

Fig. 8. (a) Fractures, stromatactoid cavities, and clotted fabrics on a polished slab collected from massive dolomitic mudstone at Outcrop 5. (b) massive dolomitic mudstone (MD) at Outcrop 5 was directly encrusted by scleractinian corals and coralline algae (Alg), then overlaid by bioclastic floatstone (Fr). The encrustation of coral Porites is indicated by black dotted lines. (c) Microphotograph showing encrusting coralline algae (Alg) and bryozoans (Bry) under transmitted light. (d) Close-up of coral encrustation and the overlying bioclastic limestone at Outcrop 5. White arrows indicate fragments of the branching coral, Acropora. 


\subsection{The Paleoenvironment before the Formation of Coral Reefs}

The occurrence of cold-seep carbonates observed at 6 outcrops (Outcrops 2 to 7 ) and in 11 borehole cores, suggests that hydrocarbon seepage occurred extensively in the Takangshan area. The compactness and association of large lucinid bivalves in massive cold-seep carbonates further indicate pronounced, long-lasting seepage of methane (Kelly et al. 2000) occurring antecedently to the development of Takangshan Reef. The carbonate pipes might have been formed as a result of sporadic expulsion of methane-related fluid seepages (Kulm and Suess 1990; Sakai et al. 1992; Campbell and Bottjer 1993; Díaz-del-Río et al. 2003). The stromatactoid cavities (Fig. 8a) occurring in a rock sample collected from Outcrop 5 were probably formed by the erosion of less indurated sediments between the well-cemented intercrusts (Peckman et al. 2002). We propose a schematic model to illustrate the occurrence of various lithologies and lithofacies associations (Fig. 9). The erosional surfaces on siliciclastic mudstones (Figs. 4a, b, 5a) and the funnel-shaped structure (Fig. 5b), as well as the exhuming of massive cold-seep carbonates (Figs. 6c, d) might have occurred concurrently during a tectonically unstable time in SW Taiwan. The deposition of fossiliferous mudstone (Figs. 5a, b) interfingered with conglomerate lithofacies (Fig. 4b) represents a rapid facies transition from a siliciclastic (non-carbonate) to a carbonate environment. The results of grain size analyses show a significant increase in the sand grade fractions of fossiliferous mudstone being due to an increase in bioclasts rather than an increased supply of coarser terrigenous siliciclastics, suggesting an environment more suitable for the initial colonization of reef-building organisms. The root of this rapid facies change is presumed to be tectonic movement, probably related to the westward thrust migration in the Pleistocene foreland basin. Although the precise geological time on these abrupt facies changes is not available, the successive occurrence of these events is probable judging by the active tectonic setting in SW Taiwan (Lacombe et al. 1997, 1999).

Although the massive cold-seep carbonates, carbonate pipes, and the conglomerate strata exposed in the E Takangshan quarry occurred with a limited lateral extent, much-wider occurrences of dolomitic cobbles and pebbles were observed from the borehole cores (Fig. 2). Many studies have proposed that violent gas escaping through the sediment surface may lead to the formation of pockmarks, craters, and brecciated carbonates (Bottjer et al. 1995; Kauffman et al. 1996; Díaz-del-Río et al. 2003). The occurrences of dolomitic lithoclasts in massive mudstones and muddy conglomerates in the study area suggest that similar events might have occurred. The funnel-like structure observed at Outcrop 7 (Fig. 5b) was likely a mud volcano conduit analogous to that of the Miocene mud volcano at Monferrato, NW Italy (Clari et al. 2004). This structure possibly served as a channel for expelling cobble- and pebble-sized mudstones onto the surrounding muddy substrata, and resulted in the occurrences of cobbles and pebbles floating in weakly consolidated matrices of siliciclastic mudstones. The conglomerate consisting of mud breccias and methane-derived carbonate was possibly a deposition resulting from mud volcano activities. It is likely that various hydrocarbon seepages occurred extensively and vigorously on the muddy seafloor of the Takangshan area before the development of coral reefs. 


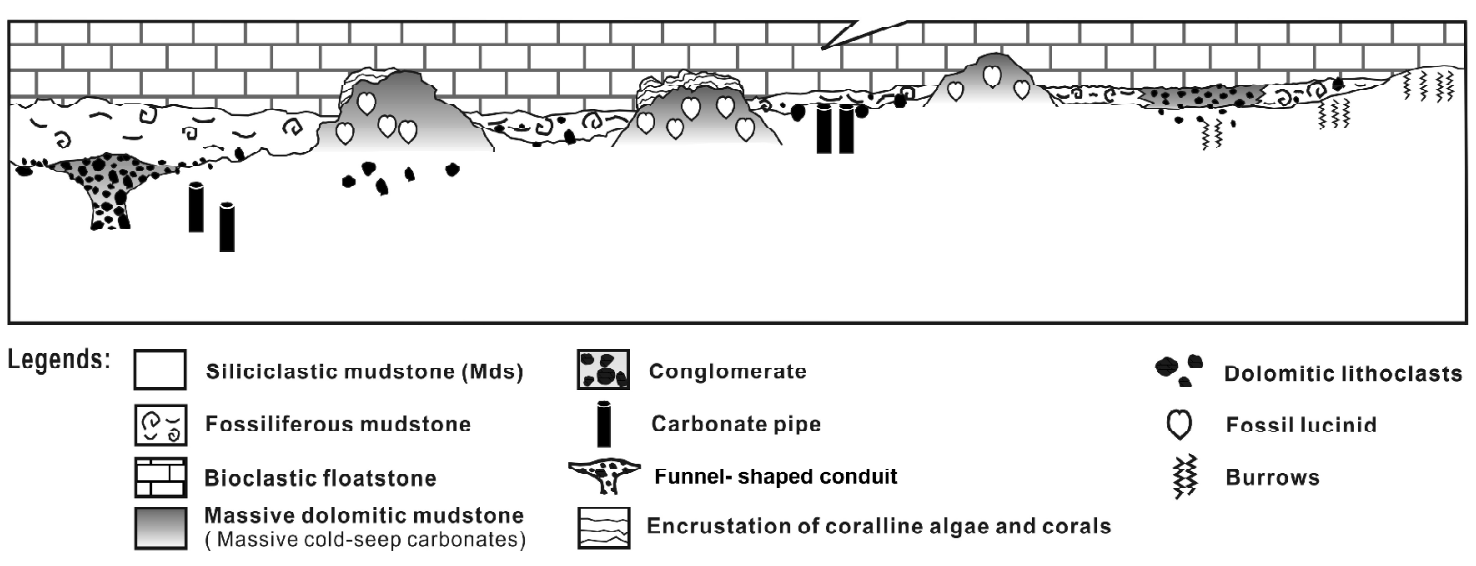

Fig. 9. A schematic model (not to scale) showing the occurrences of various lithologies and lithofacies associations.

\subsection{The Initial Development of Coral Reefs}

Reef formation is often dependent on the topography of the seabed, and topographic highs favor the colonization and growth of reef builders, especially where the substrate is a hardground or composed of coarse bioclasts (Fagerstrom 1987). At Outcrops 5 and 6, the massive coldseep carbonates were encrusted by scleractinian corals Porites, Favia, and coralline algae (Figs. 8b-d). Associations of such encrustations and massive cold-seep carbonates are unusual in the geological record. The exposed massive seep carbonates might have served as 'carbonate factories' for the surrounding muddy environments, and probably played a crucial role in the initial development of tropical coral reefs in a siliciclastic paleoenvironment of active tectonic setting. To our best knowledge, this is probably the first report that documents cold-seep carbonates acting as initial colonization hardgrounds for hermatypic corals and corallines.

\section{CONCLUSIONS}

1. Various occurrences of cold-seep carbonates were recognized at 6 outcrops and in 11 cores at the Takangshan, including massive cold-seep carbonates, carbonate pipes, and dolomitic cobbles/pebbles. The $\delta^{13} \mathrm{C}$ values of 27 rock samples of seep carbonates range from $-53.7 \%$ to $-10.4 \%$, suggesting the mixing of deep thermogenic hydrocarbons and shallow biogenic methane. The wide occurrences of seep carbonates in the study area also suggest that the hydrocarbon seeping occurred extensively.

2. A schematic model was proposed to illustrate the occurrence of various lithologies and lithofacies associations observed in the study area. The erosional surfaces on the siliciclastic mudstones and the funnel-shaped structure, as well as the exhuming of massive cold-seep 
carbonates might have occurred concurrently during a tectonically unstable time in SW Taiwan. The deposition of fossiliferous mudstone lithofacies indicate a rapid facies transition from a siliciclastic (non-carbonate) to a carbonate environment presumed to be a result of tectonic movement.

3. The encrustations of hermatypic corals and coralline algae on the massive cold-seep carbonates are unusual in the geological record, suggesting that the exposed seep carbonates played a crucial role in the initial development of coral reefs in a siliciclastic paleoenvironment.

Acknowledgements We thank Drs. K. Y. Wei, H. W. Chen, K. S. Shea, C. S. Horng, W. S. Chen, and K. S. Ho for their helpful discussions. We also thank K. M. Chuang and K. W. Chung for their assistance in the field, and C. Y. Li for the XRD analyses of rock samples. Thanks are also extended to the Universal, and Chia Hsin Cement Companies that provided the borehole cores and the permission to conduct field work in their quarries. Special thanks are given to Drs. K. A. Campbell and J. Peckmann for their valuable comments on a previous draft. This study was supported by the National Museum of Natural Science, and grants from the National Science Council, R.O.C. (NSC89-2611-M-002-036 and NSC90-2611-M-002006).

\section{REFERENCES}

Allen, J. R., and R. K. Matthews, 1982: Isotope signatures associated with early meteoric diagenesis. Sedimentology, 29, 797-817.

Bottjer, D. J., K. A. Campbell, J. K. Schubert, and M. L. Droser, 1995: Palaeoecological models, non-uniformitarianism, and tracking the changing ecology of the past. In: Bosence, D. W. J., and P. A. Allison (Eds.), Marine palaeoenvironmental analysis from fossils, Geol. Soc. Spec. Publ. No. 83. Geol. Soc., London, 7-26.

Campbell, K. A., and D. J. Bottjer, 1993: Fossil cold seeps (Jurassic-Pliocene) along the convergent margin of western North America. Nat. Geogr. Res. Explor., 9, 326-343.

Chinese Petroleum Corporation, 1989: Geological map of Tainan, scale 1:1000000, Taiwan.

Chinese Petroleum Corporation, 1992: Geological map of Kaohsiung-Pingtung, scale 1: 1000000, Taiwan.

Chow, J., J. S. Lee, C. S. Liu, B. D. Lee, and J. S. Watkins, 2001: A submarine canyon as the cause of a mud volcano- Liuchieuyu Island in Taiwan. Mar. Geol., 176, 55-63.

Clari, P., S. Cavagna, L. Martire, and J. Hunziker, 2004: A Miocene mud volcano and its plumbing system: a chaotic complex revisited (Monferrato, NW Italy).J. Sediment. Res., 74, 662676.

Conti, S., and D. Fontana, 1999: Miocene chemoherms of the northern Apennines, Italy. Geology, 27, 927-930.

De Mol, B., P. Van Rensbergen, S. Pillen, K. Van Herreweghe, D. Van Rooij, A. McDonnell, V. Huvenne, M. Ivanov, R. Swennen, and J. P. Henriet, 2002: Large deep-water coral banks in the Porcupine Basin, southwest of Ireland. Mar. Geol., 188, 193-231.

Díaz-del-Río, V., L. Somoza, J. Matínez-Frias, M. P. Mata, A. Delgado, F. J. HernandezMolina, R. Lunar, J. A. Martín-Rubí, A. Maestro, M. C. Fernández-Puga, R. León, E. 
Llave, T. Medialdea, and J. T. Vázquez, 2003: Vast fields of hydrocarbon-derived carbonate chimneys related to the accretionary wedge/olistostrome of the Gulf of Cádiz. Mar. Geol., 195, 177-200.

Fagerstrom, J. A., 1987: The evolution of reef communities, John Wiley \& Sons, New York, $600 \mathrm{pp}$.

Fisher, C. R., 1990: Chemoautotrophic and methanotrophic symbioses in marine invertebrates. Rev. Aquat. Sci., 2, 399-436.

Gaillard, C., M. Rio, Y. Rolin, and M. Roux, 1992: Fossil chemosynthetic communities related to vents or seeps in sedimentary basins: the pseudobioherms of southeastern France compared to other world examples. Palaios, 7, 451-465.

Gieskes, J. M., C. F. You, T. Lee, T. F. Yui, and H. W. Chen, 1992: Hydro-geochemistry of mud volcanoes in Taiwan. Acta Geol. Taiwan., 30, 79-88.

Gong, S. Y., T. Y. Lee, J. C. Wu, S. W. Wang, and K. M. Yang, 1996: Possible links between the development of Plio-Pleistocene coral reef limestones and thrust migration in southwestern Taiwan. J. Geol. Soc. China, 39, 151-166.

Gong, S. Y., S. W. Wang, and T. Y. Lee, 1998: Pleistocene coral reefs associated with claystones, southwestern Taiwan. Coral Reefs, 17, 215-222.

Hoeksema, B. W., and C. F. Dai, 1991: Scleractinia of Taiwan II. Family Fungiidae (including a new species). Bull. Inst. Zool. Acad. Sinica, 30, 203-228.

Hopley, D., A. M. Slocombe, F. Muir, and C. Grant, 1983: Nearshore fringing reefs in north Queensland. Coral Reefs, 1, 151-160.

Hovland, M., 1990: Do carbonate reefs form due to fluid seepage? Terra Nova, 2, 8-18.

Hovland, M., 2005: Pockmark-associated coral reefs at the Kristin field off Mid-Norway. In: Freiwald, A., and J. M. Roberts (Eds.), Cold-water corals and ecosystems. SpringerVerlag, Berlin Heidelberg, 623-632.

Hovland, M., and M. Risk, 2003: Do Norwegian deep-water coral reefs rely on seeping fluids? Mar. Geol., 198, 83-96.

Hovland, M., P. B. Mortensen, T. Brattegard, P. Strass, and K. Rokoengen, 1998: Ahermatypic coral banks off mid-Norway: evidence for a link with seepage of light hydrocarbons. Palaios, 13, 189-200.

Johnson, D. P., and M. J. Risk, 1987: Fringing reef growth on a terrigenous mud foundation, Fantome Island, central Great Barrier Reef, Australia. Sedimentology, 34, 275-287.

Kauffman, E. G., M. A. Arthur, B. Howe, and P. A.Scholle, 1996: Widespread venting of methane-rich fluids in Late Cretaceous (Campanian) submarine springs (Tepee Buttes), Western Interior seaway, U.S.A.. Geology, 24, 799-802.

Kelly, S. R. A., E. Blanc, S. P. Price, and A. G. Whitham, 2000: Early Cretaceous giant bivalves from seep-related limestone mounds, Wollaston Foreland, northeast Greenland. In: Harper, E. M., J. D. Taylor, and J. A. Crame (Eds.), The evolutionary biology of the Bivalvia, Geol. Soc. Spec. Publ. No. 177. Geol. Soc., London, 227-246.

Kulm, L. D., and E. Suess, 1990: Relationship between carbonate deposits and fluid venting: Oregon accretionary prism. J. Geophys. Res., 95, 8899-8915.

Lacombe, O., J. Angelier, H. W. Chen, B. Deffontaines, H. T. Chu, and M. Rocher, 1997: Syndepositional tectonics and extension-compression relationships at the front of the 
Taiwan collision belt: a case study in the Pleistocene reefal limestones near Kaohsiung, SW Taiwan. Tectonophys., 274, 83-96.

Lacombe, O., F. Mouthereau, B. Deffontaines, J. Angelier, H. T. Chu, and C. T. Lee, 1999: Geometry and Quaternary kinematics of fold-and-thrust units of SW Taiwan.Tectonics, 18, 1198-1223.

Lee, T. Y., 1992: Cenozoic plate reconstruction of southeast Asia and sequence stratigraphy and tectonics of the Tainan Basin, offshore southwestern Taiwan. PhD Dissertation, Univ. Texas at Austin, USA., 127 pp.

Liljedahl, L., 1992: The Silurian Ilionia prisca, oldest known deep-burrowing suspensionfeeding bivalve. J. Paleontol., 66, 206-210.

Majima, R., T. Nobuhara, and T. Kitazaki, 2005: Review of fossil chemosynthetic assemblages in Japan. Palaeogeogr. Palaeoclimatol. Palaeoecol., 227, 86-123.

McDonnell, S. L., M. D. Max, N. Z. Cherkis, and M. F. Czarnecki, 2000: Tectono-sedimentary controls on the likelihood of gas hydrate occurrence near Taiwan. Mar. Petrol. Geol., 17, 929-936.

Peckmann, J., J. L. Goedert, V. Thiel, W. Michaelis, and J. Reitner, 2002: A comprehensive approach to the study of methane-seep deposits from the Lincoln Creek Formation, western Washington State, USA. Sedimentology, 49, 855-873.

Peckmann, J., and V. Thiel, 2004: Carbon cycling at ancient methane-seeps. Chem. Geol., 205, 443-467.

Perry, C. T., 2005: Structure and development of detrital reef deposits in turbid nearshore environments, Inhaca Island, Mozambique. Mar. Geol., 214, 143-161.

Pierre, C., and J. M. Rouchy, 2004: Isotopic compositions of diagenetic dolomites in the Tortonian marls of the western Mediterranean margins: evidence of past gas hydrate dissociation. Chem. Geol., 205, 469-484.

Ritger, S., B. Carson, and E. Suess, 1987: Methane-derived authigenic carbonates formed by subduction-induced pore-water expulsion along the Oregon/Washington margin.Geol. Soc. Am. Bull., 98, 147-156.

Rogers, C. S., 1990: Responses of coral reefs and reef organisms to sedimentation.Mar. Ecol. Prog. Ser., 62, 185-202.

Sackett, W. M., 1978: Carbon and hydrogen isotope effects during the thermocatalytic production of hydrocarbons in laboratory simulation experiments. Geochim. Cosmochim. Acta, 42, 571-580.

Sakai, H., T. Gamo, Y. Ogawa, and J. Boulegue, 1992: Stable isotopic ratios and origins of the carbonates associated with cold seepage at the eastern Nankai Trough.Earth Planet. Sci. Lett., 109, 391-404.

Sanders, D., and R. C. Baron-Szabo, 2005: Scleractinian assemblages under sediment input: their characteristics and relation to the nutrient input concept. Palaeogeogr. Palaeoclimat. Palaeoecol., 216, 139-181.

Scoffin, T. P., and M. D. A. Le Tissier, 1998: Late Holocene sea level and reef-flat progradation, Phuket, south Thailand. Coral Reefs, 17, 273-276.

Shih, T. T., 1967: A survey of the active mud volcanoes in Taiwan and a study of their types and the character of the mud. Petrol. Geol. Taiwan, 5, 259-311. 
Taylor, J. D., and E. A. Glover. 2000: Functional anatomy, chemosymbiosis and evolution of the Lucinidae. In: Harpe, E. M., J. D. Taylor, and J. A. Crame (Eds.), The evolutionary biology of the Bivalvia, Geol. Soc. Spec. Publ. No. 177. Geol. Soc., London, 207-225.

Teng, L. S., 1992: Geotectonic evolution of Tertiary continental margin basins of Taiwan. Petrol. Geol. Taiwan., 27, 1-19.

Tudhope, A. W., and T. P. Scoffin, 1994: Growth and structure of fringing reefs in a muddy environment, south Thailand. J. Sediment. Res., A64, 752-764.

Weiss, M. P., D. A. Goddard, and X. Picard, 1978: Marine geology of reefs and inner shelf, Chichiriviche, Estado Falcon, Venezuela. Mar. Geol., 28, 211-244.

Whiticar, M. J., 1999: Carbon and hydrogen isotope systematics of bacterial formation and oxidation of methane. Chem. Geol., 161, 291-314.

Woodroffe, C. D., D. M. Kennedy, D. Hopley, C. E. Rasmussen, and S. G. Smithers, 2000: Holocene reef growth in Torres Strait. Mar. Geol., 170, 331-346.

Yabe, H., and T. Sugiyama, 1935a: Geological and geographical distribution of reef-corals in Japan. J. Paleont., 9, 187-217.

Yabe, H and T. Sugiyama, 1935b: Revised lists of the reef corals from the Japanese seas and of the fossil reef corals of the raised reefs and the Ryukyu Limestone of Japan.J. Geol. Soc. Jpan., 42, 379-403.

Yang, T. F., G. H. Yeh, C. C. Fu, C. C. Wang, T. F. Lan, H. F. Lee, C. H. Chen, V. Walia, and Q. C. Sung, 2004: Composition and exhalation flux of gases from mud volcanoes in Taiwan. Environ. Geol., 46, 1003-1011.

Yeh, G. H., T. F. Yang, J. C. Chen, Y. G. Chen, and S. R. Song, 2005: Fluid geochemistry of mud volcanoes in Taiwan. In: Martinelli, G., and B. Panahi (Eds.), Mud volcanoes, Geodynamics and Seismicity. Springer, 227-237.

You, C. F., J. M. Gieskes, T. Lee, T. F. Yui and H. W. Chen, 2004: Geochemistry of mud volcano fluids in the Taiwan accretionary prism. Appl. Geochem., 19, 695-707.

Yu, S. B., H. Y. Chen, and L. C. Kuo, 1997: Velocity field of GPS stations in the Taiwan area. Tectonophysics, 274, 41-59.

Wang, S. W., Gong, S. Y., Mii, H. S., and Dai, C. F., 2006: Cold-seep carbonate hardgrounds as the initial substrata of coral reef development in a siliciclastic paleoenvironment of southwestern Taiwan. Terr. Atmos. Ocean. Sci., 17, 405-427. 